Supporting Information

\title{
Tumor microenvironment-regulated and reported nanoparticles for overcoming the self-confinement of multiple photodynamic therapy
}

Cheng Li, ${ }^{\dagger, \S}$, Xianchuang Zheng ${ }^{\ddagger, \S}$, Weizhi Chen ${ }^{\dagger, \S}$, Shilu Ji ${ }^{\dagger}$, Yang Yuan ${ }^{\dagger}$, Xiqun Jiang ${ }^{*}, \dagger$

†Department of Polymer Science \& Engineering, College of Chemistry \& Chemical

Engineering, Nanjing University, Nanjing 210023, China

Institute of Nanophotonics, Jinan University, Guangzhou 511443, China

${ }^{\S}$ These authors contributed equally to this work.

*Corresponding Author: Email: jiangx@nju.edu.cn 
Materials: IrPVP is synthesized according to our previous work. ${ }^{1} \mathrm{~V}_{2} \mathrm{O}_{5}$ nanoparticles were synthesized according to the literature. ${ }^{2}$ Ammonium metavanadate, losartan, and Hexadecyltrimethyl ammonium bromide (CTAB) were purchased from Beijing Innochem Co., Ltd. 1-(3-(Dimethylamino)propyl)-3-ethylcarbodiimide hydrochloride (EDC), acryloyl chloride, succinic anhydride, and 3-aminopropyltriethoxysilane (APTES) were purchased from Shanghai J\&K Company. Dulbecco's Modified Eagle Medium (DMEM) and fetal bovine serum (FBS) and ROS sensitive probe SOSG were purchased from Jiangsu Keygen Biotechnology Co., Ltd. Other organic reagents were purchased from Nanjing Wanqing Chemical Glass ware \& instrument Co., Ltd.

Synthesis of 4-oxo-4-((3-(triethoxysilyl)propyl)amino)butanoic acid (1). APTES (221 mg, $1 \mathrm{mmol})$ and succinic anhydride (100 mg, $1 \mathrm{mmol})$ were dissolved in $20 \mathrm{~mL}$ anhydrous DCM. After stirring overnight in room temperature, the solvent was evaporated by a rotary evaporator under reduced pressure to obtain Compound 1 . ${ }^{1} \mathrm{HNMR}\left(400 \mathrm{MHz}, \mathrm{CDCl}_{3}\right): \delta=3.75(\mathrm{t}, 6 \mathrm{H}), 3.00(\mathrm{t}, 2 \mathrm{H}), 2.42(\mathrm{t}, 2 \mathrm{H}), 2.29(\mathrm{t}, 2 \mathrm{H})$, $1.43(\mathrm{~m}, 2 \mathrm{H}), 1.15(\mathrm{t}, 9 \mathrm{H}), 0.53(\mathrm{t}, 3 \mathrm{H}) .[\mathrm{M}+\mathrm{Na}]^{+}=344.15$.

Synthesis of APTES-Losartan. Compound 1 (321 mg, 1 mmol), EDC (230 mg, 1.2 mmol), and a tip of DMAP were dissolved in $20 \mathrm{~mL}$ anhydrous THF and stirred in ice bath for 10 minutes. Then losartan $(500 \mathrm{mg}, 1.2 \mathrm{mmol})$ in anhydrous THF (30 mL) was dropwise added and stirred overnight in room temperature. The precipitate was filtrated and the solvent was removed under reduced pressure. Then the residue was purified by chromatography on a silica gel column with THF/EtOAc (4/1) to give the compound APTES-Losartan. ${ }^{1} \mathrm{HNMR}\left(400 \mathrm{MHz}, \mathrm{CDCl}_{3}\right): \delta=7.47(\mathrm{~d}, 2 \mathrm{H}), 7.38(\mathrm{~d}, 4 \mathrm{H}), 7.23(\mathrm{~m}$, 
2H), $5.19(\mathrm{~s}, 1 \mathrm{H}), 5.02(\mathrm{~s}, 1 \mathrm{H}), 3.78(\mathrm{~m}, 6 \mathrm{H})), 3.35(\mathrm{t}, 2 \mathrm{H}), 3.19(\mathrm{t}, 2 \mathrm{H}), 2.51(\mathrm{t}, 2 \mathrm{H})$, $2.43(\mathrm{t}, 2 \mathrm{H}), 1.45-1.53(\mathrm{~m}, 4 \mathrm{H}), 1.24(\mathrm{~m}, 2 \mathrm{H}), 1.16(\mathrm{t}, 9 \mathrm{H}), 0.87(\mathrm{t}, 2 \mathrm{H}) 0.56(\mathrm{t}, 3 \mathrm{H})$. $[\mathrm{M}+\mathrm{Na}]^{+}=748.35$.

Synthesis of N-(3-(triethoxysilyl)propyl)acrylamide (2). APTES (220 mg, $1 \mathrm{mmol}$ ) and triethylamine (200 mg, $2 \mathrm{mmol}$ ) were dissolved in $20 \mathrm{~mL}$ anhydrous DCM and stirred for 10 minutes in ice bath. Then acryloyl chloride (180 mg, $2 \mathrm{mmol})$ in DCM $(10 \mathrm{~mL})$ was dropwise added. After stirring in room temperature overnight, the precipitate was filtrated and the solvent was evaporated under reduced pressure. The residue was purified by chromatography on a silica gel column with DCM/EtOAc (8/1) to give the compound 2. ${ }^{1} \mathrm{HNMR}\left(400 \mathrm{MHz}, \mathrm{CDCl}_{3}\right): \delta=6.54(\mathrm{~m}, 1 \mathrm{H}), 6.48(\mathrm{~d}, 2 \mathrm{H})$, $5.78(\mathrm{~d}, 2 \mathrm{H}), 3.83(\mathrm{~m}, 6 \mathrm{H}), 3.43(\mathrm{t}, 2 \mathrm{H}), 2.58(\mathrm{t}, 2 \mathrm{H}), 2.48(\mathrm{t}, 2 \mathrm{H}), 1.68(\mathrm{~m}, 2 \mathrm{H}), 1.23$ $(\mathrm{t}, 9 \mathrm{H}), 0.66(\mathrm{t}, 3 \mathrm{H}) .[\mathrm{M}+\mathrm{Na}]^{+}=298.15$.

Synthesis of IrPVP-APTES. IrPVP $(900 \mathrm{mg}, 0.06 \mathrm{mmol})$, n-hexylamine $(70 \mu \mathrm{L})$ and a catalytic amount of TCEP were dissolved in $15 \mathrm{~mL}$ anhydrous DMF and stirred overnight in room temperature under argon protection. Then compound $2(100 \mathrm{mg})$ in anhydrous DMF $(3 \mathrm{~mL})$ was added and the reaction mixture was stirred at room temperature for another 24 hours under argon protection. After that, the solution was precipitated in anhydrous diethyl ether twice to give IrPVP-APTES. ${ }^{1} \mathrm{HNMR}(400 \mathrm{MHz}$, CDCl3): $\delta=9.34(\mathrm{~d}, 1 \mathrm{H}), 9.21(\mathrm{~d}, 1 \mathrm{H}), 8.73(\mathrm{~d}, 1 \mathrm{H}), 8.67(\mathrm{~d}, 1 \mathrm{H}), 8.46(\mathrm{~d}, 1 \mathrm{H}), 8.39$ (d, 1H), 8.04-7.99 (m, 2H), $7.90(\mathrm{t}, 2 \mathrm{H}), 7.76(\mathrm{t}, 1 \mathrm{H}), 7.73(\mathrm{~d}, 1 \mathrm{H}), 7.58(\mathrm{~d}, 1 \mathrm{H}), 7.52(\mathrm{t}$, 1H), 7.09-7.04 (m, 2H), $6.91(\mathrm{~m}, 2 \mathrm{H}), 6.71(\mathrm{~m}, 1 \mathrm{H}), 6.49-6.42(\mathrm{~m}, 5 \mathrm{H}), 6.35-6.30(\mathrm{~m}$, 2H), $5.78(\mathrm{~d}, 2 \mathrm{H}), 5.18(\mathrm{~s}, 1 \mathrm{H}), 3.72(\mathrm{~m}, 125 \mathrm{H}), 3.21(\mathrm{~m}, 248 \mathrm{H}), 2.36-1.41(\mathrm{~m}, 741 \mathrm{H})$, 
$1.21(\mathrm{t}, 9 \mathrm{H}), 0.56(\mathrm{t}, 3 \mathrm{H})$.

Preparation of IrP@ $\mathbf{V}_{2} \mathbf{O}_{5}$ and IrP-L@ $\mathbf{V}_{2} \mathbf{O}_{5}$ nanoparticles. $200 \mathrm{mg}$ of IrPVPAPTES, $1 \mu \mathrm{L}$ TEOS and $10 \mathrm{mg}$ of $\mathrm{V}_{2} \mathrm{O}_{5}$ nanoparticles were added into $50 \mathrm{~mL}$ of anhydrous toluene and sonicated for $0.5 \mathrm{~h}$. The solution was heated to $120{ }^{\circ} \mathrm{C}$ and refluxed for $24 \mathrm{~h}$. The resulting solid was washed 5 times with toluene and then dried in vacuum to give the product $\mathrm{IrP} @ \mathrm{~V}_{2} \mathrm{O}_{5}$. IrP-L@ $\mathrm{V}_{2} \mathrm{O}_{5}$ was prepared by reacting $65 \mathrm{mg}$ of IrP@ $\mathrm{V}_{2} \mathrm{O}_{5}$ with $10 \mathrm{mg}$ of Losartan-APTES using a similar method as mentioned above. The amount of IrPVP and Losartan conjugated to the $\mathrm{V}_{2} \mathrm{O}_{5}$ nanoparticle core was determined by fluorescence spectra and HPLC analysis, respectively. The samples were treated with cold $\mathrm{HCl}(0.1 \mathrm{mM})$ prior to HPLC analysis.

Measurement of singlet oxygen quantum yield. Singlet oxygen quantum yields $(\Phi \Delta)$ were measured by monitoring the absorbance of 1,3-diphenylisobenzofuran (DPBF). Briefly, a solution of IrP-L@ $\mathrm{V}_{2} \mathrm{O}_{5}\left(1 \mathrm{mg} \mathrm{mL}^{-1}\right)$ containing $30 \mu \mathrm{M}$ DPBF was prepared in the dark and irradiated with a $635 \mathrm{~nm}$ laser at a power of $200 \mathrm{~mW} \mathrm{~cm}^{-2}$ with an interval of $1 \mathrm{~s}$. DPBF oxidation was monitored by UV-Vis spectrophotometer. The $\Phi \Delta$ values were calculated using methylene blue $(\mathrm{MB})$ in $\mathrm{DMF}(\Phi \Delta=0.52)$ as the standard. Hypoxia-response of IrP-L@ $\mathrm{V}_{2} \mathrm{O}_{5}$ nanoparticles. The aqueous solution of IrPL@ $\mathrm{V}_{2} \mathrm{O}_{5}$ nanoparticles $\left(1 \mathrm{mg} \mathrm{mL}^{-1}\right)$ was bubbled with the mixed gas of nitrogen and oxygen for 30 minutes. The ratio of the mixed gas was adjusted with a flow meter. Then the cuvette was sealed and the emission spectra of sample under various oxygen levels were detected on a Horiba Jobin Yvon FluoroMax-4 NIR fluorescence spectrophotometer (excitation: $540 \mathrm{~nm}$ ). 
In vitro singlet oxygen generation assay. A $5 \mathrm{mM}$ stock solution was prepared by dissolving $100 \mathrm{mg}$ SOSG in $33 \mu \mathrm{L}$ methanol. Then the sample solution (1 mL) was added with $2.5 \mu \mathrm{L}$ of SOSG stock solution and irradiated with a $635 \mathrm{~nm}$ laser $(200 \mathrm{~mW}$ $\mathrm{cm}^{-2}$ ). The fluorescence intensity of SOSG was recorded with an excitation wavelength of $504 \mathrm{~nm}$ and an emission wavelength of $525 \mathrm{~nm}$.

Oxygen partial pressure measurement in vitro. IrPVP, $\mathrm{IrP} @ \mathrm{~V}_{2} \mathrm{O}_{5}$, and $\operatorname{IrP}-\mathrm{L} @ \mathrm{~V}_{2} \mathrm{O}_{5}$ were dissolved in water or aqueous solution of $\mathrm{H}_{2} \mathrm{O}_{2}(50 \mu \mathrm{M})$ to a concentration of 1.00, 1.08 , or $1.22 \mathrm{mg} \mathrm{ml}^{-1}$ in $5 \mathrm{~mL}$ centrifuge tubes. All the samples contained the same concentration of IrPVP component $\left(1 \mathrm{mg} \mathrm{mL}^{-1}\right)$. The oxygen partial pressure of the samples was immediately measured using the Oxylite oxygen meter for 5 minutes (Oxford, UK). After that, the solution samples were exposed to $635 \mathrm{~nm}$ laser (200 $\mathrm{mW}$ $\mathrm{cm}^{-2}$ ) for 3 minutes, and then measured for 2 minutes. This cycle was repeated for 1 hour.

In vitro cytotoxicity of IrP-L@ $@ \mathbf{V}_{2} \mathbf{O}_{5}$ nanoparticles. $\mathrm{H} 22$ cells $\left(2 \times 10^{4}\right.$ cells per well $)$ were incubated with different concentrations of IrPVP, IrP@ $\mathrm{V}_{2} \mathrm{O}_{5}$ and IrP-L@ $@ \mathrm{~V}_{2} \mathrm{O}_{5}$ for $24 \mathrm{~h}$, then MTT solution ( $5 \mathrm{mg} \mathrm{mL}^{-1}$ ) was added to the medium. After 4 hours of incubation, $100 \mu \mathrm{L}$ aqueous solution containing $10 \mathrm{~g}$ sodium dodecyl sulfate, $5 \mathrm{ml}$ isobutanol, and $0.1 \mathrm{~mL} 10 \mathrm{M} \mathrm{HCl}$ was added to each well, followed with incubation for another $24 \mathrm{~h}$. Then the absorbance of MTT at $570 \mathrm{~nm}$ was measured.

To evaluate the phototoxicity of IrP-L@ $@ \mathrm{~V}_{2} \mathrm{O} 5, \mathrm{H} 22$ cells were seeded in 96-well plates and added with IrPVP, IrP@ $\mathrm{V}_{2} \mathrm{O}_{5}$ or IrP-L@ $\mathrm{V}_{2} \mathrm{O}_{5}$ at various concentrations, followed with incubation for 4 hours. Then, the cells were incubated under normoxic $\left(21 \% \mathrm{O}_{2}\right)$ 
or hypoxic condition $\left(0 \% \mathrm{O}_{2}\right)$ for another 1 hour. After that, the cells were irradiated with a $635 \mathrm{~nm}$ laser at a power density of $200 \mathrm{~mW} \mathrm{~cm}^{-2}$ for 5 minutes, and further cultured in an incubator for 24 hours. The cellular viability was measured by MTT assay as described above.

Oxygen sensing of IrP-L@ $\mathbf{V}_{2} \mathbf{O}_{5}$ nanoparticles. $\mathrm{H} 22$ cells were seeded in a 6-well plate and incubated for four hours at $37{ }^{\circ} \mathrm{C}$ in a DMEM containing $10 \%$ fetal bovine serum. IrPVP, IrP@ $\mathrm{V}_{2} \mathrm{O}_{5}$ or IrP-L@ $\mathrm{V}_{2} \mathrm{O}_{5}$ in PBS was added to the cell culture medium to a final concentration of $5 \mathrm{mg} \mathrm{mL}^{-1}$. The cells were co-cultured with the nanoparticles for 4 hours and washed three times with PBS. Then the cells were cultured for 1 hour under different oxygen atmospheres $(21,10$ and $0 \%)$ and observed under a laser confocal microscope (Zeiss LSM-710).

Measurement of cell hypoxia. $\mathrm{H} 22$ cells were incubated with $\operatorname{IrPVP}, \operatorname{IrP} @ \mathrm{~V}_{2} \mathrm{O}_{5}$ or IrP-L@ $\mathrm{V}_{2} \mathrm{O}_{5}$ nanoparticles in DMEM containing 10\% fetal bovine serum for 4 hours. Then the cells were irradiated for 5 minutes at $635 \mathrm{~nm}\left(200 \mathrm{~mW} \mathrm{~cm}^{-2}\right)$ and observed by laser confocal microscopy.

Generation of intracellular singlet oxygen. H22 cells were seeded in 6-well plates and cultured for 4 hours with nanoparticles. Then the medium was removed and the cells were incubated with $10 \mu \mathrm{M}$ SOSG for 30 minutes, followed with incubation for 1 hour under normoxic or hypoxic conditions. The cells were then irradiated for 5 minutes at $635 \mathrm{~nm}\left(200 \mathrm{~mW} \mathrm{~cm}^{-2}\right)$ and observed by laser confocal microscopy.

Animal model. ICR mice were bought from the Animal center of Drum-tower Hospital and performed in accord with guidelines provided by the Animal Care Committee at 
Drum-Tower Hospital (Nanjing, China). $100 \mu \mathrm{L}$ of $\mathrm{H} 22$ cells $\left(2 \times 10^{6}\right)$ in PBS suspension was injected into the right posterior side of each mouse to establish H22 tumors. When the tumor size reached approximately $80 \mathrm{~mm}^{3}$, the in vivo experiments were performed. Oxygen partial pressure measurement in vivo. Mice bearing $\mathrm{H} 22$ tumors were randomly divided into three groups (six mice in each group) and intravenously injected with IrPVP, IrP@ $\mathrm{V}_{2} \mathrm{O}_{5}$ or IrP-L@ $\mathrm{V}_{2} \mathrm{O}_{5}\left(60 \mathrm{mg} \mathrm{mL}^{-1}\right.$ IrPVP in $200 \mu \mathrm{L}$ PBS). The oxygen partial pressure of the tumor tissue was measured using the Oxylite (Oxford, UK). The probe was inserted directly into the tumor tissue to the depth of approximately $2-3 \mathrm{~mm}$ to take the reading.

Tumor hypoxia imaging. IrPVP, IrP@ $\mathrm{V}_{2} \mathrm{O}_{5}$ or IrPL@ $\mathrm{V}_{2} \mathrm{O}_{5}$ in PBS $(200 \mu \mathrm{L}, 60$ mg $\mathrm{mL}^{-1}$ ) was injected into the tumor-bearing mice through the tail vein. Mice were anesthetized with isoflurane and imaged using IVIS in vivo imaging system at various time points after injection.

Tumor hypoxia imaging after irradiation. IrPVP, $\operatorname{IrP} @ \mathrm{~V}_{2} \mathrm{O}_{5}$ or $\operatorname{IrP}-\mathrm{L} @ \mathrm{~V}_{2} \mathrm{O}_{5}$ was injected into tumor-bearing mice through the tail vein, and the tumor tissues were irradiated with laser $\left(635 \mathrm{~nm}, 200 \mathrm{~mW} \mathrm{~cm}^{-2}\right)$ for five minutes at 24 hours after injection. Mice were anesthetized with isoflurane and imaged with IVIS in vivo imaging system. In vivo anti-tumor effect. $\mathrm{H} 22$ tumor-bearing mice were divided into 8 groups $(5$ mice in each group), and then treated with PBS with or without laser irradiation, IrPVP (60 mg kg $\left.{ }^{-1}\right)$ with or without laser irradiation, IrP@ $\mathrm{V}_{2} \mathrm{O}_{5}\left(60 \mathrm{mg} \mathrm{kg}^{-1} \mathrm{IrPVP}\right)$ with or without laser irradiation, or IrP-L@ $\mathrm{V}_{2} \mathrm{O}_{5}\left(60 \mathrm{mg} \mathrm{kg}^{-1}\right.$ IrPVP) with or without laser irradiation on day 1, 3 and 5 through tail veil. The mice in laser irradiation groups were 
exposed to $635 \mathrm{~nm}$ laser $\left(200 \mathrm{mw} \mathrm{cm}^{-2}\right)$ for 5 minutes in day 2, 4 and 6 . After different treatment, the tumor size and body weight were measured every other day. The tumor volume was measured by a Vernier caliper, which was calculated as $V=a \times b^{2} / 2$ (a was the longer diameter and $\mathrm{b}$ was the shorter diameter of the tumor). The relative volume evaluated by $\mathrm{V} / \mathrm{V}_{0}$, where $\mathrm{V}_{0}$ was the initial tumor volume before treatment. After the measurement in day 15 , the mice were sacrificed and the tumor tissues were collected and weighed.

In vivo anti-tumor effect of fPDT. H22 tumor-bearing mice were divided into 4 groups ( 5 mice in each group), The first group was treated with PBS $(0.1 \mathrm{mM}, 100 \mu \mathrm{L})$, The second group was treated with IrP-L@ $\mathrm{V}_{2} \mathrm{O}_{5}\left(60 \mathrm{mg} \mathrm{kg}^{-1} \mathrm{IrPVP}\right)$ on day 1, and then irradiated the tumor on day 2. The third group was treated with IrP-L@ $\mathrm{V}_{2} \mathrm{O}_{5}(60 \mathrm{mg}$ $\mathrm{kg}^{-1} \mathrm{IrPVP}$ ) on day 1 , and then irradiated the tumor on day 2, 4 and 6 . The forth group was treated with IrP-L@ $\mathrm{V}_{2} \mathrm{O}_{5}\left(60 \mathrm{mg} \mathrm{kg}^{-1} \mathrm{IrPVP}\right)$ on day 1, 3 and 5 and then irradiated the tumor on day 2, 4 and 6. After different treatment, the tumor size and body weight were measured every other day.

Immunofluorescence staining. H22 tumors were harvested at $24 \mathrm{~h}$ after three injections of the nanoparticles. Tumors were fixed in $4 \%$ paraformaldehyde for $4 \mathrm{~h}$ at $4{ }^{\circ} \mathrm{C}$, incubated in $30 \%$ sucrose solution for $24 \mathrm{~h}$ and frozen in Optimal Cutting Temperature (O.C.T.) embedding medium. $9 \mu \mathrm{m}$ sections were cut for histological analysis. For immunostaining, tumor sections were incubated with mouse antipimonidazole (1:200, Hypoxyprobe Inc.), CD 31 (1:300, BD), aSMA (1:200, Abcam), or Col-1 (1:200, Abcam) antibody and Alex 488 or 595-conjugated secondary antibody 
$(1: 1000, \mathrm{BD})$ following the manufacturer's instructions.

Tumor perfusion. Tumor perfusion were processed according to the literature. ${ }^{3}$ Briefly, H22 tumor bearing mice were injected with $10 \mathrm{mg} \mathrm{kg}^{-1}$ Hoechst 33342 through tail vein at $24 \mathrm{~h}$ after three injections of the nanoparticles. The mice were anesthetized with isoflurane at 10 min after administration with Hoechst 33342, and then perfused 5 min with $10 \mathrm{mM}$ PBS through heart. Tumors were fixed in 4\% paraformaldehyde for $4 \mathrm{~h}$ at $4{ }^{\circ} \mathrm{C}$, incubated in $30 \%$ sucrose solution for $24 \mathrm{~h}$ and frozen in Optimal Cutting Temperature (O.C.T.) embedding medium. $9 \mu \mathrm{m}$ sections were cut for histological analysis.

Statistical analysis. All data are expressed as means \pm SD. Statistical differences were performed using student's t test and one-way ANOVA with GraphPad Prism 8.0 software (GraphPad Software Inc., USA). P $<0.05$ was considered statistically significant. Vessel density and vessel number was analyzed by ImageJ. 
Table S1. Optimization of chemical composition in the obtained IrP-L@ $\mathrm{V}_{2} \mathrm{O}_{5}$ nanoparticles.

\begin{tabular}{|c|c|c|c|c|}
\hline $\begin{array}{c}\mathbf{V}_{\mathbf{2}} \mathbf{O}_{\mathbf{5}} \\
\mathbf{( m g}\end{array}$ & $\begin{array}{c}\text { IrPVP } \\
(\mathbf{m g})\end{array}$ & $\begin{array}{c}\text { Losartan } \\
(\mathbf{m g})\end{array}$ & $\begin{array}{c}\text { Obtained ratio } \\
\left(\mathbf{V}_{\mathbf{2}} \mathbf{O}_{\mathbf{5}}: \text { IrPVP }: \text { Losartan }\right)\end{array}$ & Notes \\
\hline 10 & 100 & 10 & $1: 9.4: 0.9$ & $\begin{array}{c}\text { Lower IrPVP and } \\
\text { Losartan content }\end{array}$ \\
\hline 10 & 100 & 20 & $1: 9.4: 1.7$ & Lower IrPVP content \\
\hline 10 & 100 & 30 & $1: 9.4: 1.9$ & Lower IrPVP content \\
\hline 10 & 200 & 10 & $1: 12: 0.8$ & Lower Losartan content \\
\hline 10 & 200 & 20 & $1: 12: 1.6$ & Best material ratio \\
\hline 10 & 200 & 30 & $1: 12: 1.6$ & Waste of material \\
\hline 10 & 400 & 10 & $1: 12: 0.8$ & Lower Losartan content \\
\hline 10 & 400 & 20 & $1: 12: 1.6$ & Waste of material \\
\hline 10 & 400 & 30 & $1: 12: 1.6$ & Waste of material \\
\hline
\end{tabular}




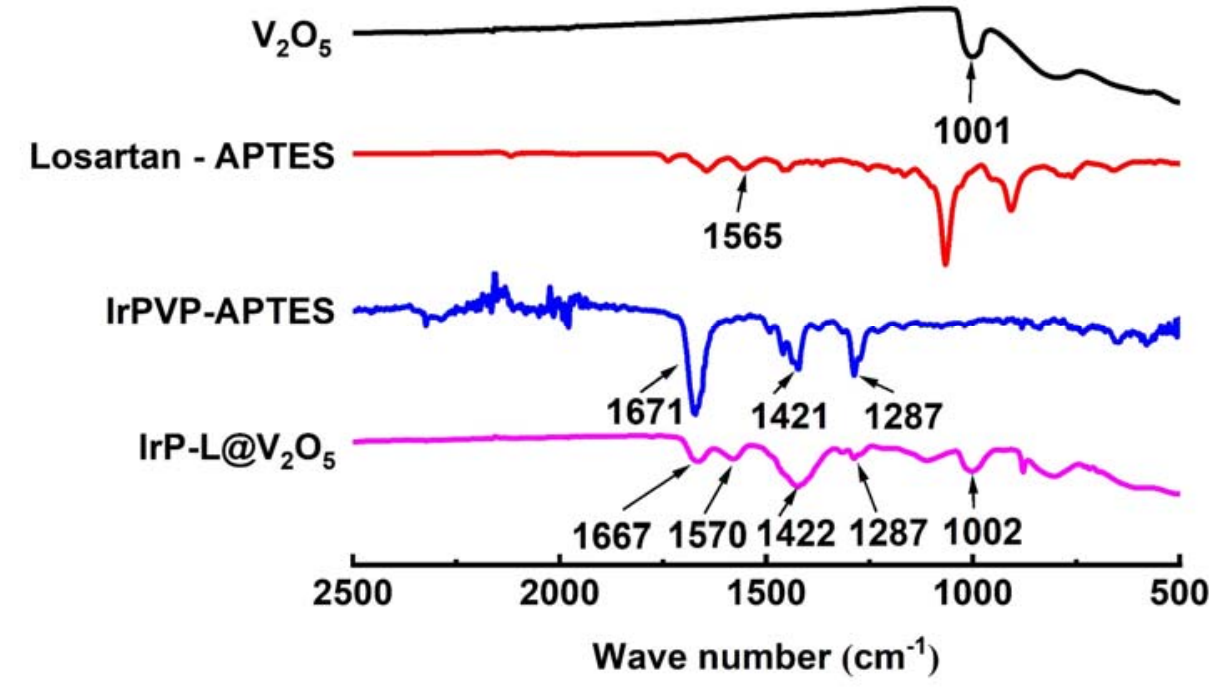

Figure S1. FT-IR spectra of $\mathrm{V}_{2} \mathrm{O}_{5}$, Losartan-APTES, IrPVP-APTES, and IrP-L@ $@ \mathrm{~V}_{2} \mathrm{O}_{5}$. 

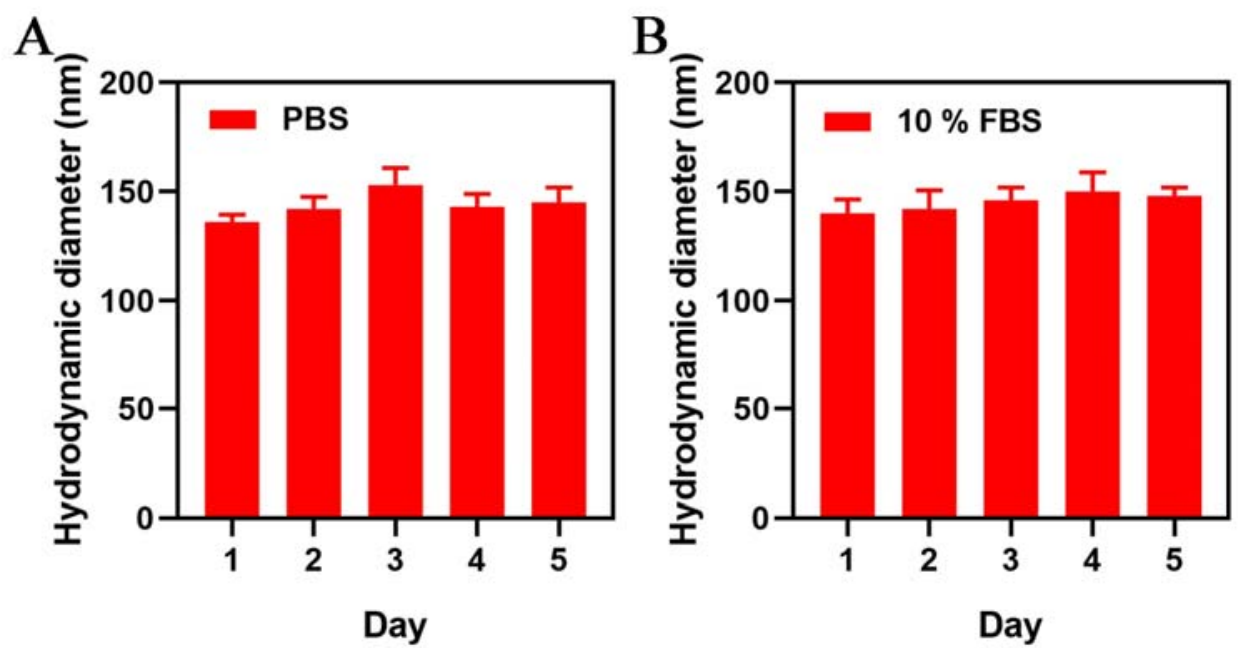

Figure S2. The evolution of hydrodynamic diameter of the IrP-L@ $\mathrm{V}_{2} \mathrm{O}_{5}$ nanoparticles in PBS (A) and $10 \%$ FBS (B) solution over 5 days at room temperature. 


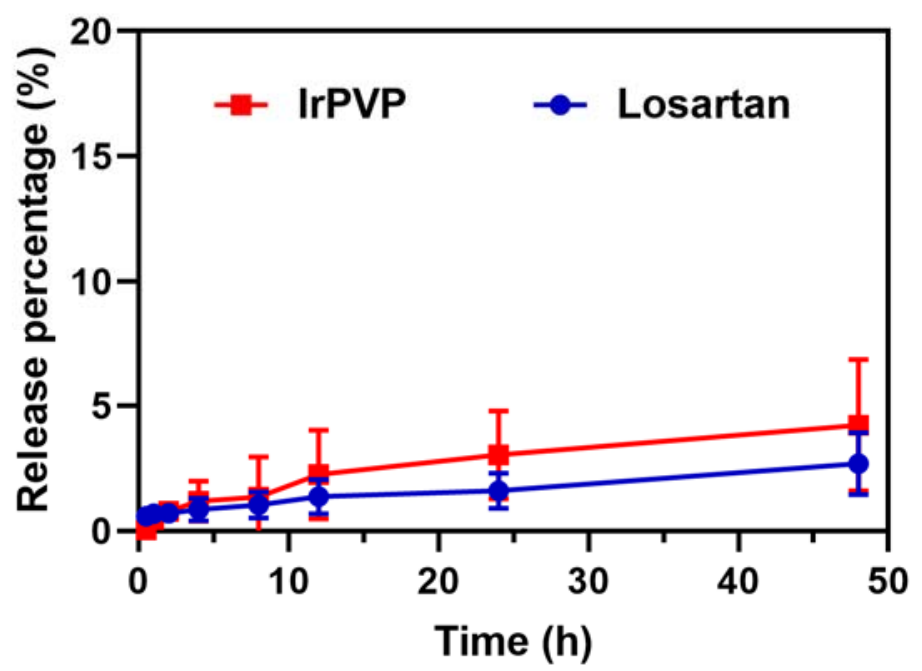

Figure S3. The release profile of the IrPVP and losartan components from the IrP$\mathrm{L} @ \mathrm{~V}_{2} \mathrm{O}_{5}$ nanoparticles in PBS solution. 


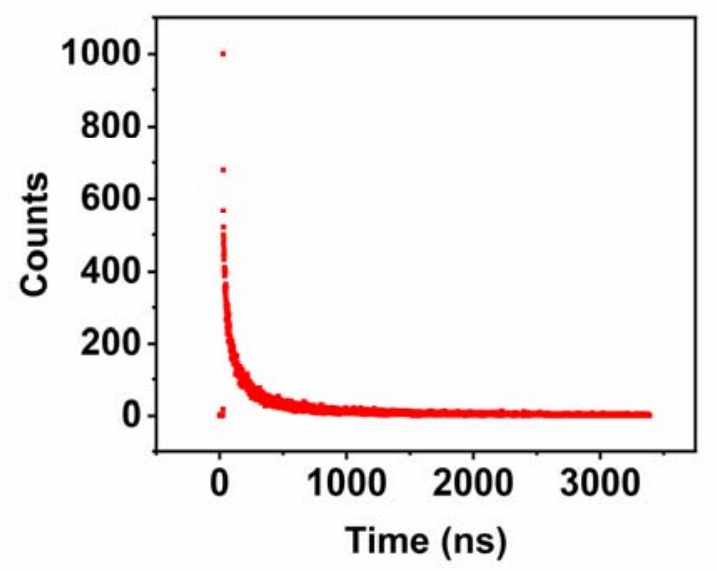

Figure S4. Phosphorescence lifetime of IrP-L@ $\mathrm{V}_{2} \mathrm{O}_{5}$ in air-balanced aqueous solution. 

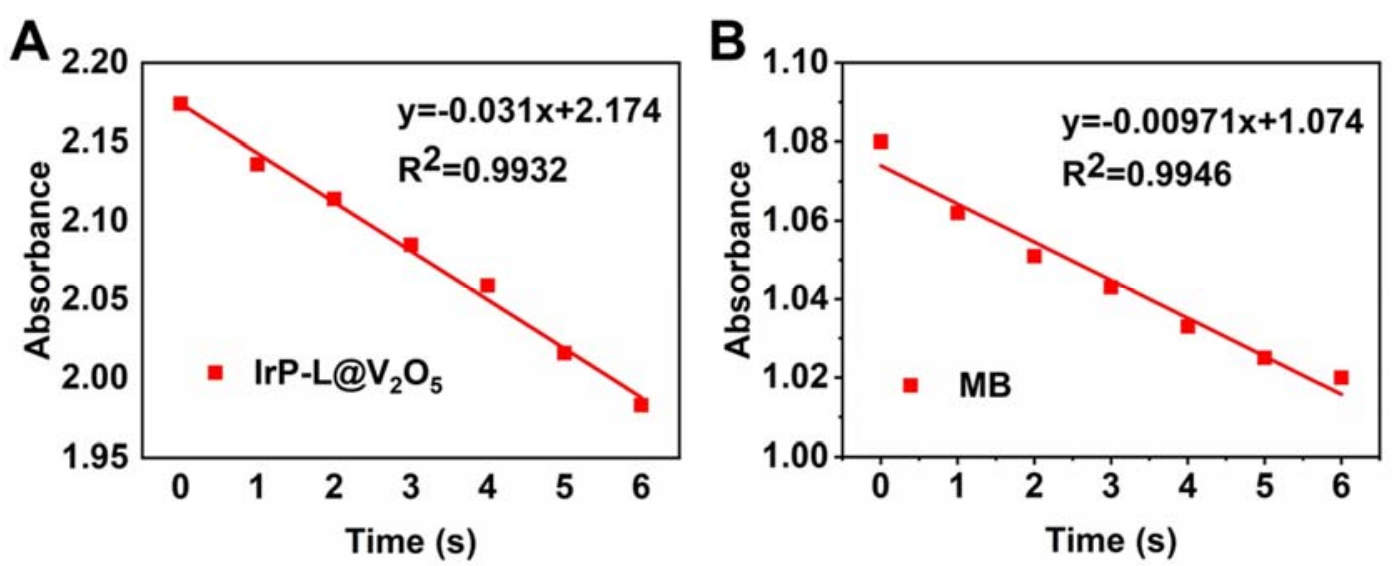

Figure S5. Singlet oxygen quantum yield of nanoparticulate system. (A) Absorbance of DPBF in IrP-L@ $\mathrm{V}_{2} \mathrm{O}_{5}$ solution $\left(1 \mathrm{mg} \mathrm{mL}^{-1}\right)$ irradiated for different durations with $635 \mathrm{~nm}$ laser $\left(200 \mathrm{~mW} \mathrm{~cm}^{-2}\right)$. (B) Absorbance of DPBF in methylene blue solution irradiated for different durations with $635 \mathrm{~nm}$ laser $\left(200 \mathrm{~mW} \mathrm{~cm}^{-2}\right)$. 


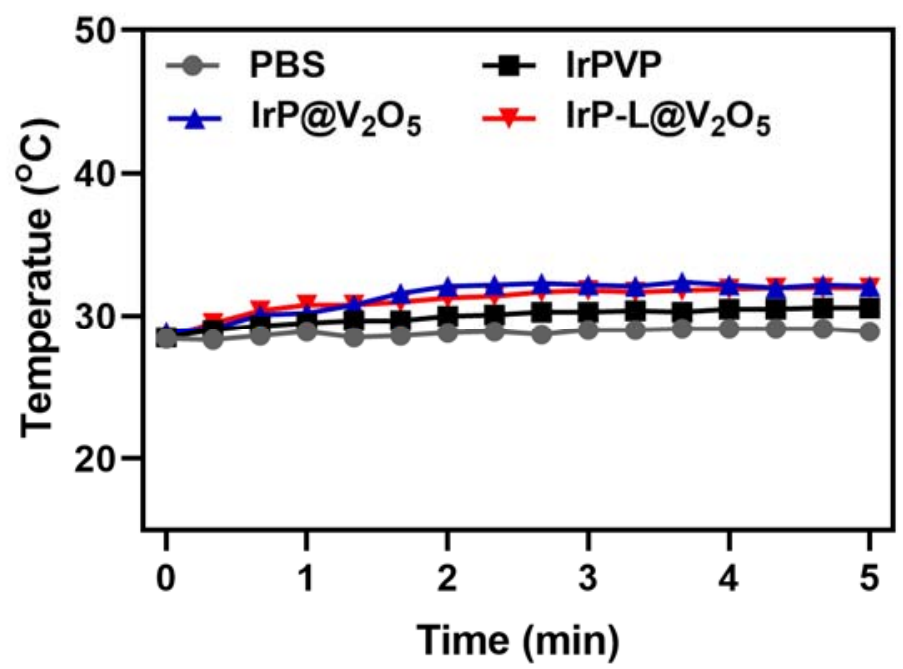

Figure S6. The photothermal effect of PBS, IrPVP, IrP@ $\mathrm{V}_{2} \mathrm{O}_{5}$, and IrP-L@ $\mathrm{V}_{2} \mathrm{O}_{5}$ under laser irradiation $\left(635 \mathrm{~nm}, 200 \mathrm{~mW} \mathrm{~cm}{ }^{-2}, 5 \mathrm{~min}\right)$. The IrPVP concentration was $1 \mathrm{mg}$ $\mathrm{mL}^{-1}$ for the three latter groups. 
A

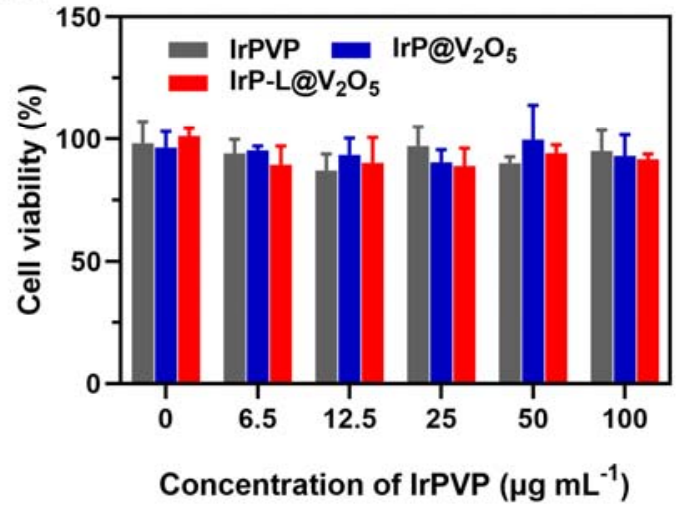

B

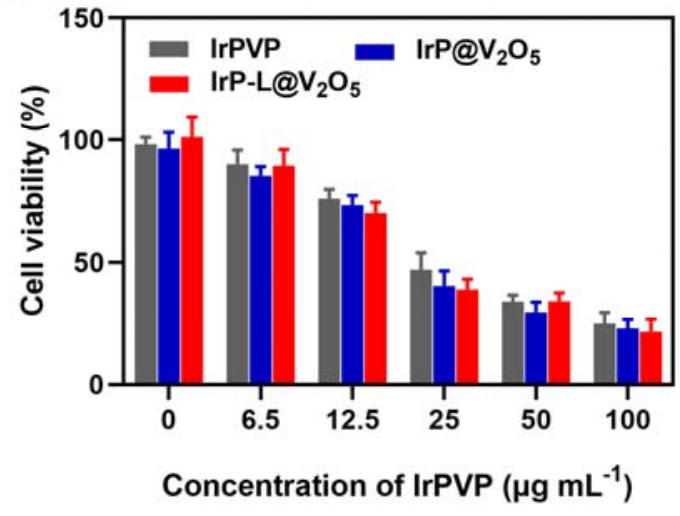

Figure S7. Cytotoxicity of nanoparticulate system in H22 cells. (A) Cell viability of H22 tumor cells treated with different concentration of nanoparticles without light irradiation. (B) Cell viability of $\mathrm{H} 22$ tumor cells treated with different concentration of nanoparticles with $635 \mathrm{~nm}$ laser irradiation $\left(200 \mathrm{~mW} \mathrm{~cm}^{-2}\right)$ in five minutes under normoxia condition. 

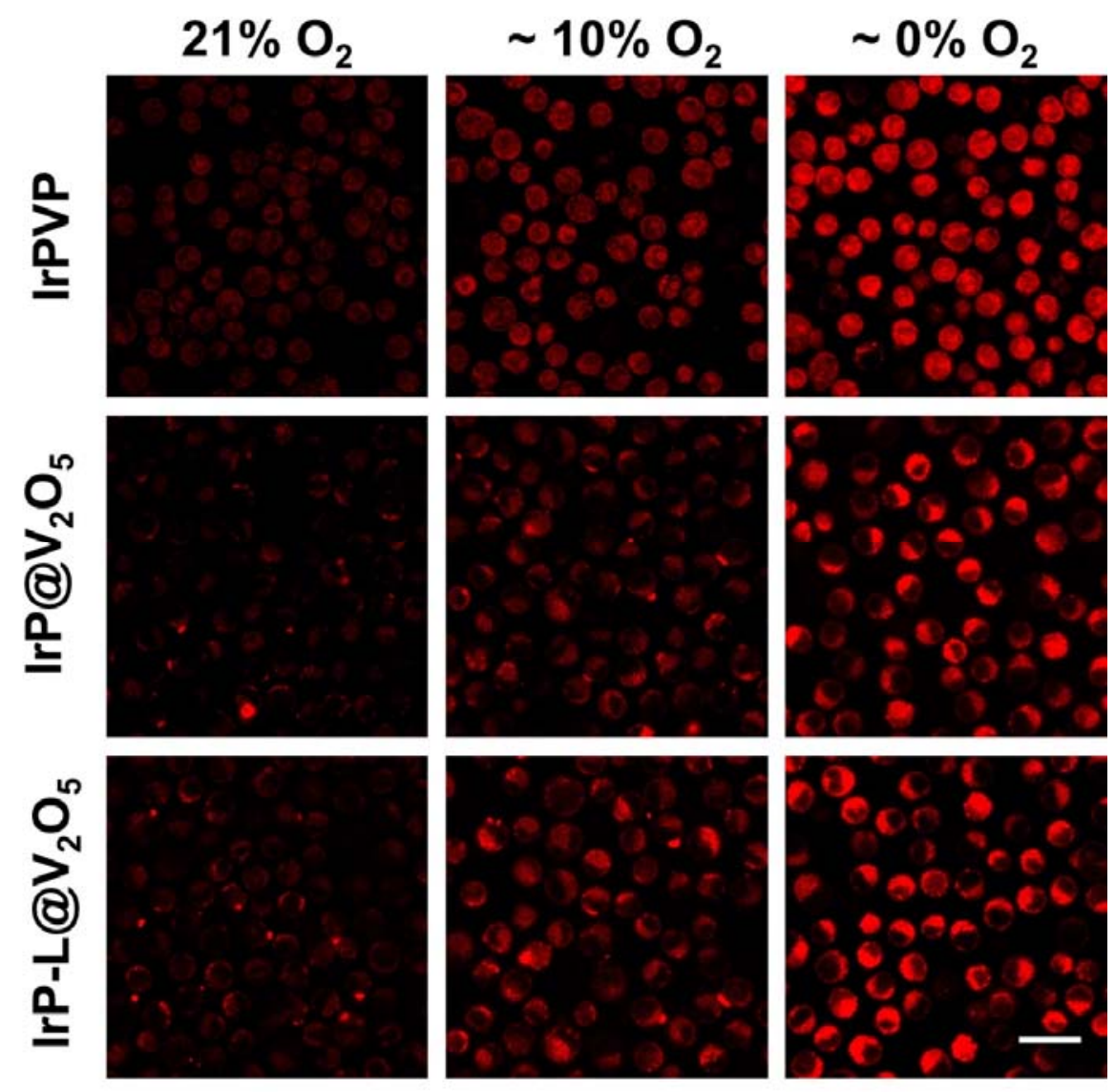

Figure S8. Oxygen sensing by nanoparticulate system in vitro. Oxygen sensing ability of $\mathrm{H} 22$ tumor cells treated with IrPVP, IrP@ $\mathrm{V}_{2} \mathrm{O}_{5}$ and IrP-L@ $\mathrm{V}_{2} \mathrm{O}_{5}$ in different oxygen concentration. Scale bar: $10 \mu \mathrm{m}$. 


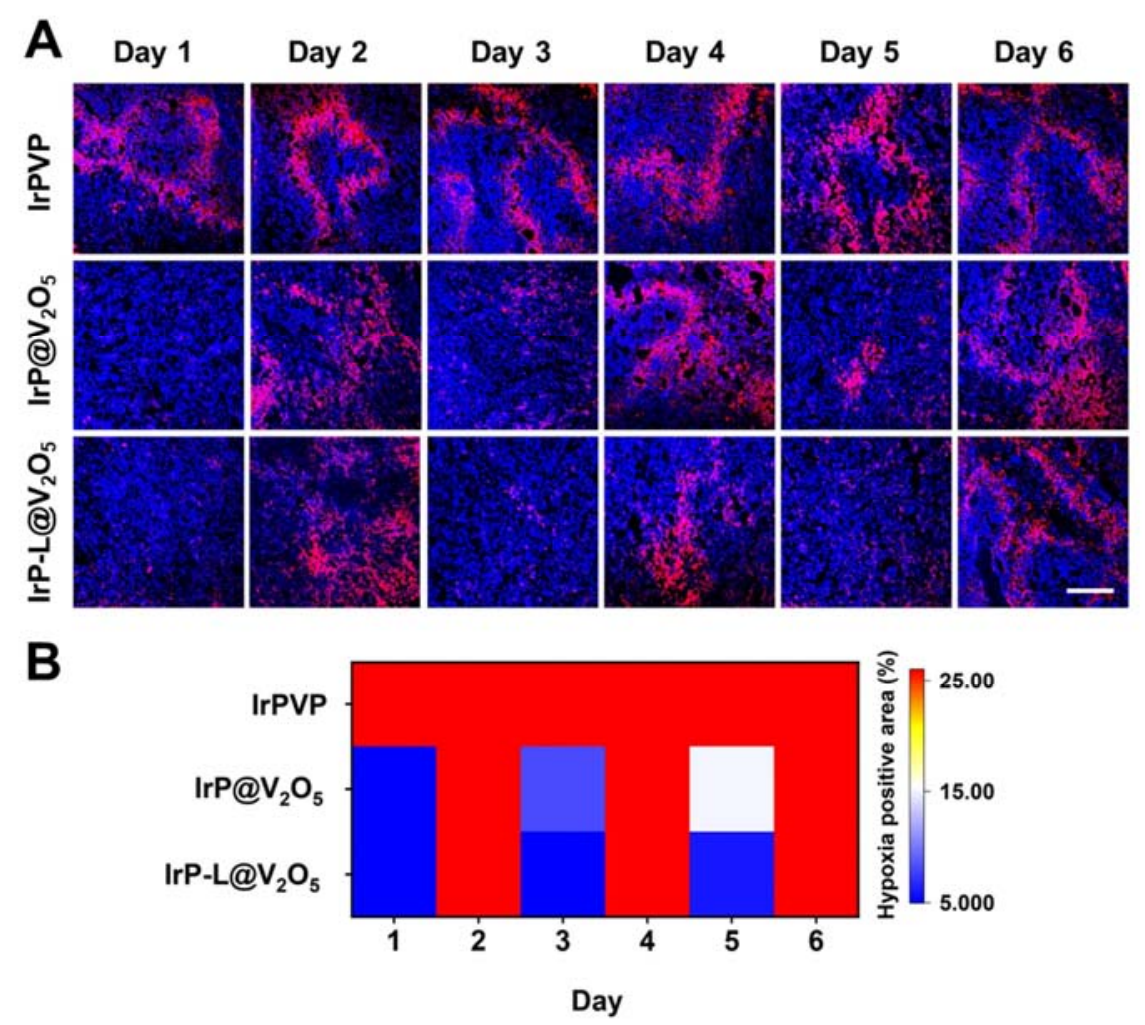

Figure S9. Immunofluorescent staining of Pimonidazole during fPDT. (A) Immunofluorescent staining of Pimonidazole (red) in $\mathrm{H} 22$ tumor after three times treatment and three times irradiation in six days. Scale bar: $100 \mu \mathrm{m}$. (B) Hypoxia positive area of Pimonidazole in $\mathrm{H} 22$ tumor. 

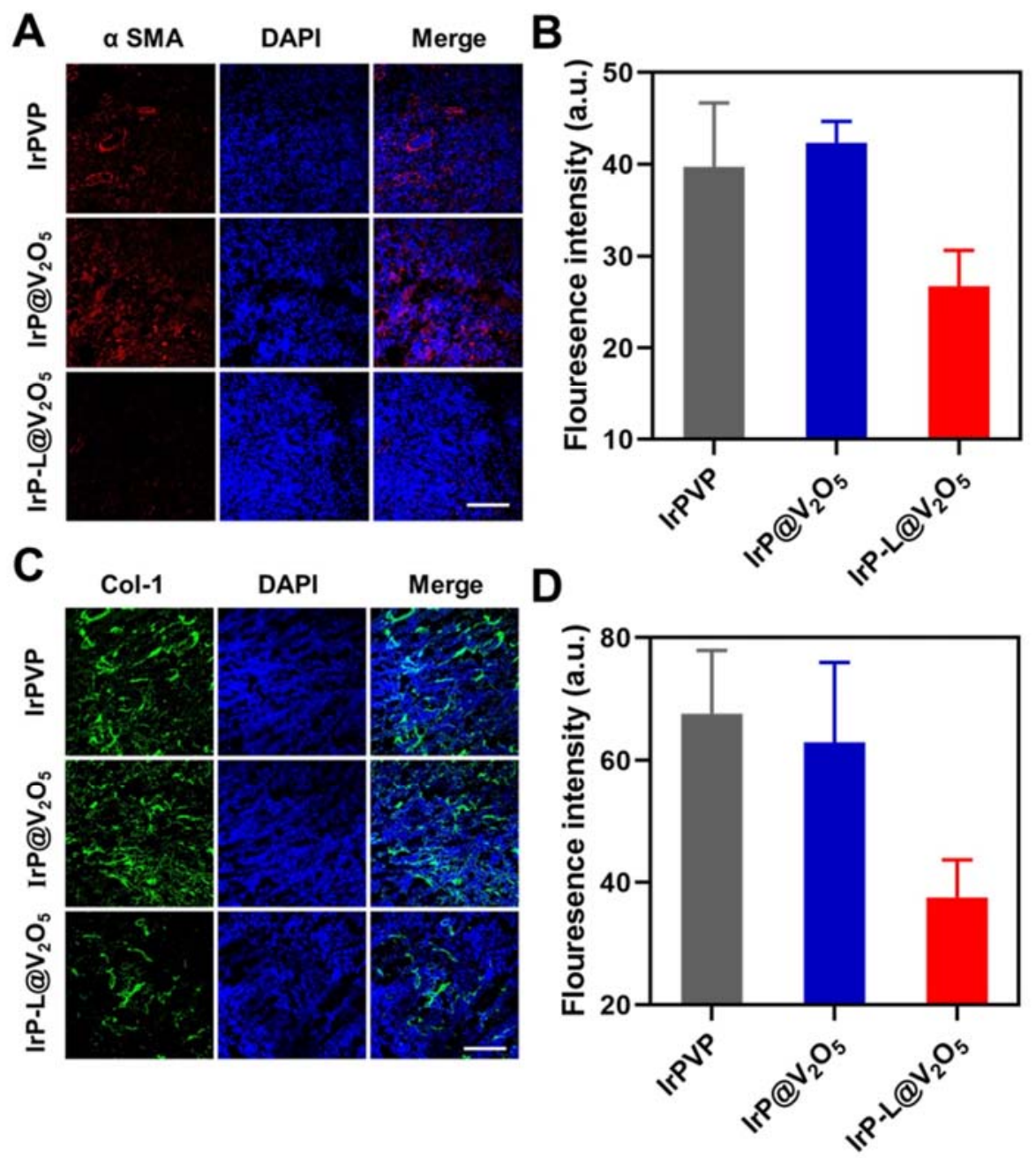

Figure S10. Tumor microenvironment remodeling by nanoparticulate system. (A) Immunofluorescent staining of $\alpha \mathrm{SMA}$ (red) in $\mathrm{H} 22$ tumor after three times treatment in five days. Scale bar: $100 \mu \mathrm{m}$. (B) Semi quantitative fluorescence intensity of $\alpha$ SMA in H22 tumor. (C) Immunofluorescent staining of collagen-1 (Col-1) (green) in H22 tumor after three times treatment in five days. Scale bar: $100 \mu \mathrm{m}$. (D) Semi-quantitative fluorescence intensity of Col-1 in H22 tumor. 

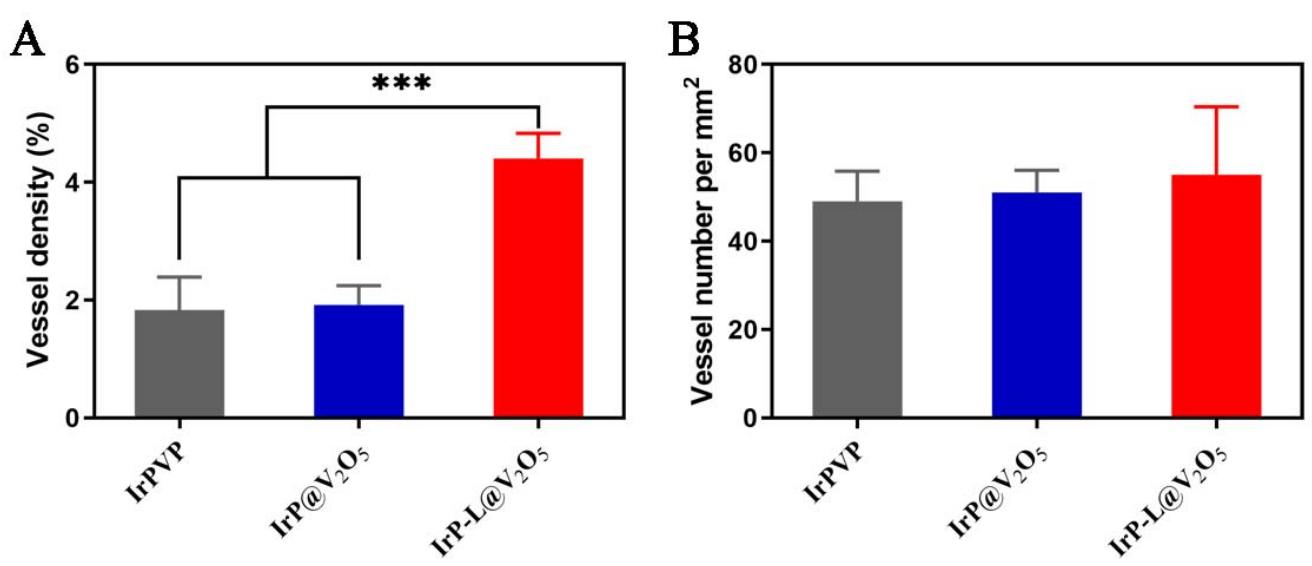

Figure S11. Quantitative result of blood vessel density (A) and number (B) after treatment with various nanoparticles for three times. $* * * \mathrm{P}<0.001$, statistical analyses were performed with one-way ANOVA. 

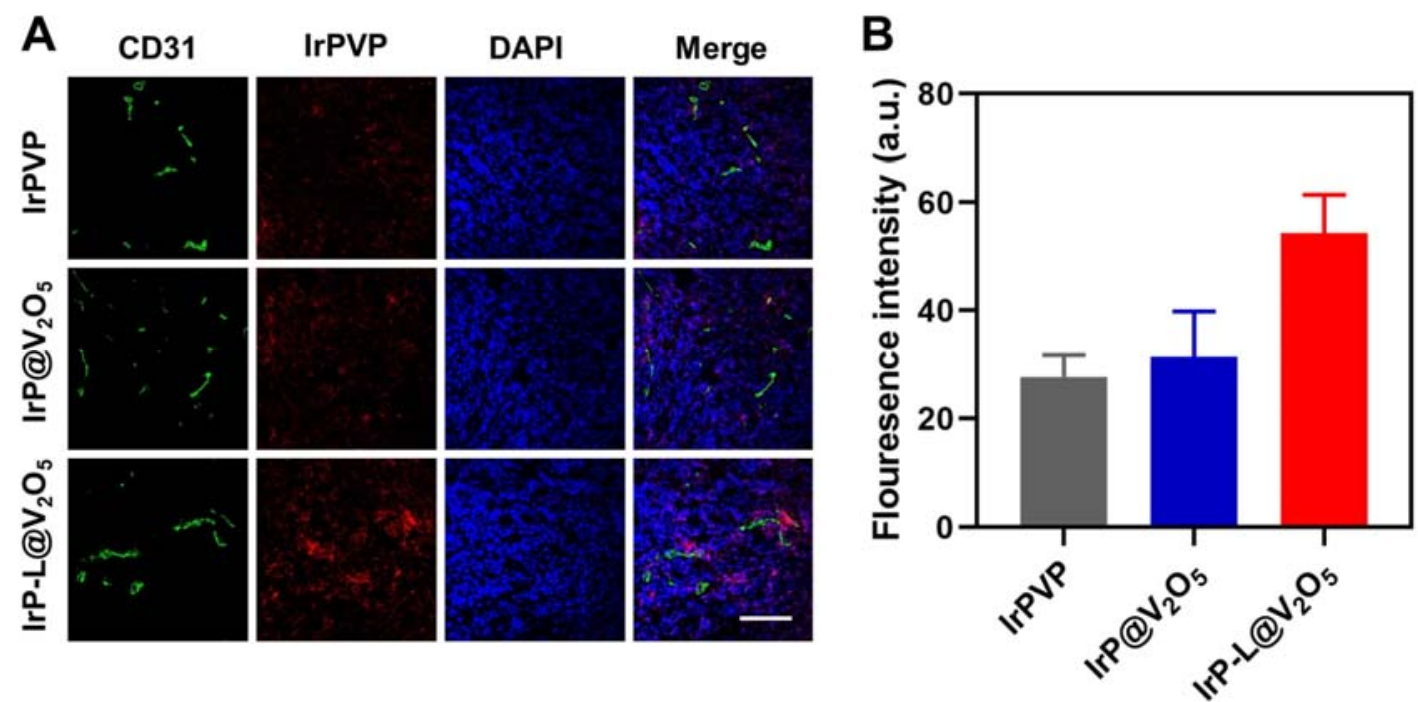

Figure S12. Penetration of nanoparticle in H22 tumor. (A) Immunofluorescence staining sections of CD31 (green) in H22 tumor tissue and different nanoparticles (red) penetrated in tumor after three times injection in five days. Scale bar: $100 \mu \mathrm{m}$. (B) Semiquantitative fluorescence intensity of different nanoparticles in $\mathrm{H} 22$ tumor. 

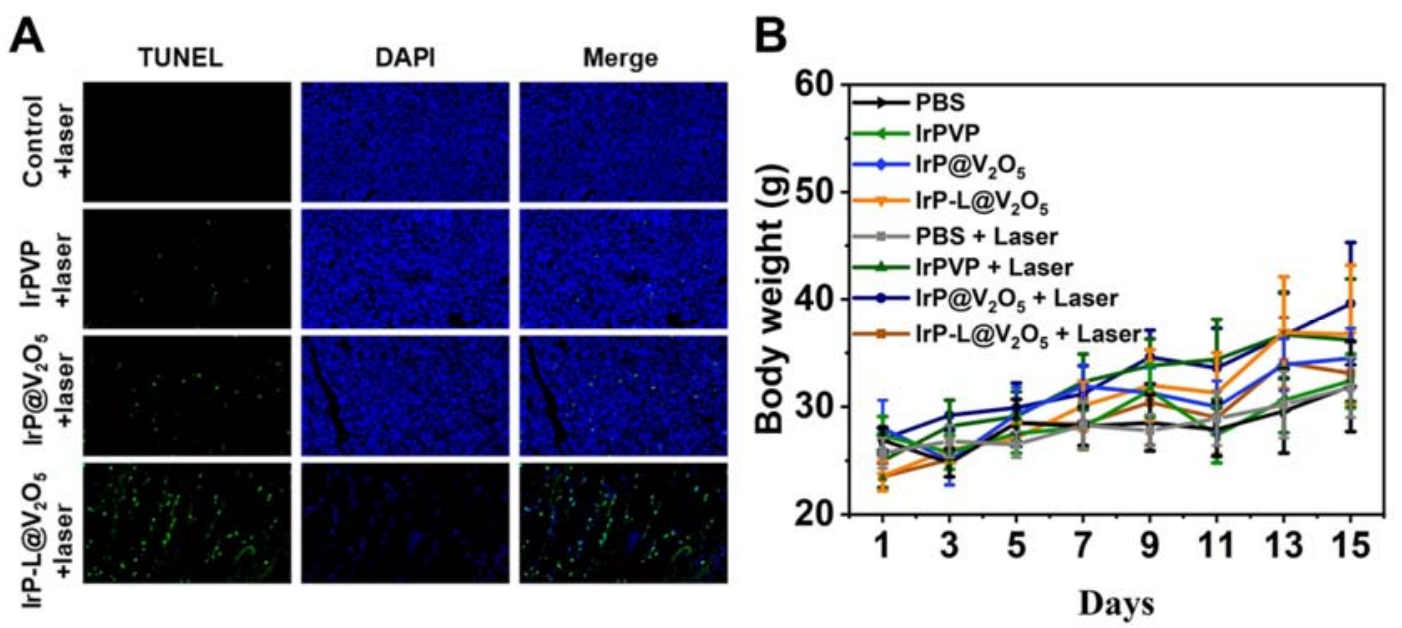

Figure S13. Antitumor efficiency of nanoparticulate system after fPDT. (A) TUNEL staining of the tumor tissues after different treatment of fPDT on day 15. (B) Body weights of $\mathrm{H} 22$ tumor bearing mice with different treatments. 


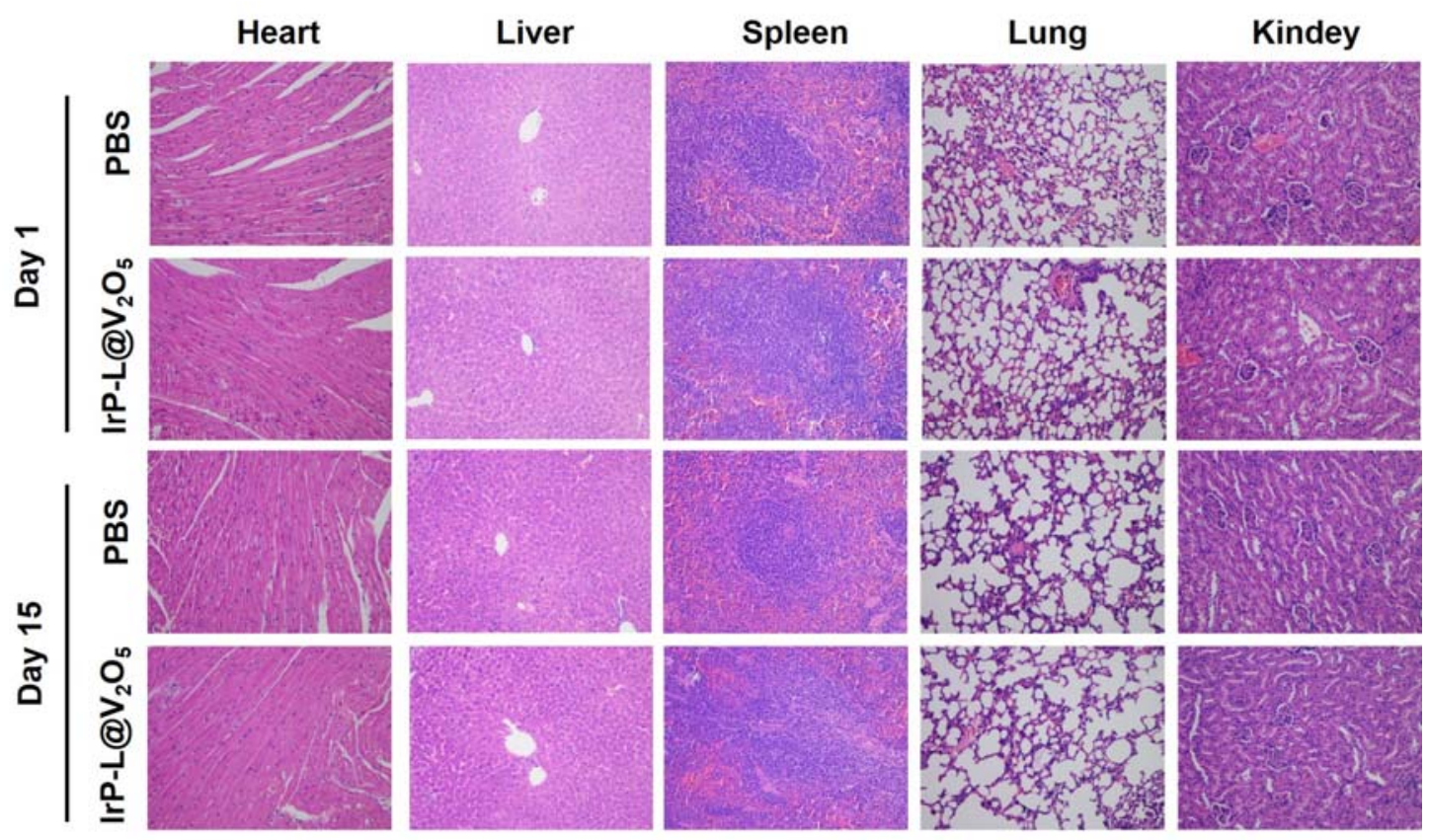

Figure S14. H\&E staining of major organs from the mice at Day 1 and Day 15 after i.v. injection of IrP-L@ $\mathrm{V}_{2} \mathrm{O}_{5}\left(60 \mathrm{mg} \mathrm{kg}^{-1} \mathrm{IrPVP}\right)$.

\section{References}

(1) Zheng, X.; Wang, X.; Mao, H.; Wu, W.; Liu, B.; Jiang, X. Hypoxia-Specific Ultrasensitive Detection of Tumours and Cancer Cells in Vivo. Nat. Commun. 2015, 6, 6834. DOI: 10.1038/ncomms6834.

(2) Asim, N.; Radiman, S.; Yarmo, M. A.; Banaye Golriz, M. S. Vanadium Pentoxide: Synthesis and Characterization of Nanorod and Nanoparticle $\mathrm{V}_{2} \mathrm{O}_{5}$ Using CTAB Micelle Solution. Microporous Mesoporous Mater. 2009, 120 (3), 397-401. DOI:10.1016/j.micromeso.2008.12.013.

(3) Rahbari, N. N.; Kedrin, D.; Incio, J.; Liu, H.; Ho, W. W.; Nia, H. T.; Edrich, C. M.; Jung, K.; Daubriac, J.; Chen, I.; Heishi, T.; Martin, J. D.; Huang, Y.; Maimon, 
N.; Reissfelder, C.; Weitz, J.; Boucher, Y.; Clark, J. W.; Grodzinsky, A. J.; Duda, D. G.; Jain, R. K.; Fukumura, D. Anti-VEGF Therapy Induces ECM Remodeling and Mechanical Barriers to Therapy in Colorectal Cancer Liver Metastases. Sci. Transl. Med. 2016, 8 (360), 1-12. DOI: 10.1126/scitranslmed.aaf5219. 